\title{
Analysis of long term hydrological records to assess the changing regime and pathways in oil shale mining districts of North East Estonia
}

\author{
R. Vaht ${ }^{1}$, W. M. Mayes ${ }^{2}$, M. Sepp ${ }^{1}$, A. Järvet ${ }^{1} \&$ Ü. Mander ${ }^{1}$ \\ ${ }^{I}$ Department of Geography, Institute of Ecology and Earth Sciences, \\ University of Tartu, Estonia \\ ${ }^{2}$ Centre for Environmental and Marine Sciences, University of Hull, UK
}

\begin{abstract}
This paper documents long term (1923-2005) changes in surface drainage areas and run-off characteristics in two small to medium $\left(100-1000 \mathrm{~km}^{2}\right)$ rivers draining part of the Ordovician oil shale field of north east Estonia. The changing regime in the heavily mined catchments is contrasted with a morphologically similar reference catchment (River Keila) where there has been no mining activity. Coupling of flow regime with mining records (discharge rates and workings locations) is undertaken to assess the impact of expansion in oil shale mining through the mid to late $20^{\text {th }}$ century on downstream flow regime and pathways. The study shows that during phases of intense mining, summer baseflow is between $53-72 \%$ higher than long term average baseflow in the Purtse catchment and between 66-92\% higher in the smaller Pühajõgi catchment where the volumetric significance of mine discharges is greater. The Keila catchment does not show any significant change in summer baseflow during the study period suggesting that the changes in the Pühajõgi and Purtse are not controlled by climatic drivers. Assessment of mine flow records highlights the significant augmentation of baseflow in the mined catchments.

Keywords: hydrological regime, baseflow, minimum run-off, mine water.
\end{abstract}




\section{Introduction}

Mining pollution has been found to be a major to be a control on the dispersal of contaminant metals and metalloids at local, regional [1] and global scales [2] and management options for minimising such contaminant releases, particularly to the aquatic environment, have advanced greatly over the last 20 years e.g. [3, 4]. Some of the most pervasive and understudied effects of mining on the environment are however due to physical changes in flowpaths and regimes [3]. These are often difficult to identify given the lack of long term hydrological datasets to assess the significance of any mining-related changes (i.e. before and after datasets). This is particularly the case in the largely abandoned orefields of Western Europe and parts of North America.

There is some evidence of changing catchment hydrology in restored coal mining districts of Appalachia (USA). In [5], a paired catchment study of water balances is employed to show changes in the hydrological behavior of a surface mined (and subsequently reclaimed) catchment relative to an adjacent reference catchment. Ferrari et al. [6] similarly highlighted the trend towards a flashy hydrograph more indicative of urban catchments than pre-mining conditions in other reclaimed coal mined catchments in Appalachia.

In analogous settings, the effects of large scale limestone extraction and associated pumping operations have been well documented in affecting downstream regime. Winter flow augmentation (due to increased void dewatering efforts) and diminished summer flows due to the effects of cone of depression development reducing spring flows have been identified at some sites (e.g. $[7,8])$.

The hydrogeological regime and water chemistry in North East Estonia Ordovician oil shale mining area has been studied widely over the last thirty years (e.g. [9-11]). Recently, a variety of models have been used in groundwater studies $[12,13]$ to assess the impacts of oil shale mining on hydrogeology which inform this current research. Previous analyses [14, 15] have briefly demonstrated the impact of mining on hydrological regime and run-off in small to medium Estonian river systems (taken here to be a size range of $100-1000$ $\mathrm{km}^{2}$ ).

This paper assesses the impact of changes in drainage associated with Estonian oil shale mining on hydrological pathways and regime in small (River Pühajõgi) and medium (River Purtse) sized lowland catchments. The long term regime in these mine-impacted systems is compared with the morphologically similar River Keila catchment, which offers a useful reference catchment where no mining development has taken place. The unusually long period of hydrometric record in these systems (from 1923-2005) provides a rare opportunity to assess changes in run-off characteristics over time as a result of mining operations. A particular focus on baseflow changes is provided. Through the combined assessment of long-term hydrological and mining records, the impact of various phases of oil shale mining operations can be assessed in multiscale catchments. 


\section{Material and methods}

\subsection{Study area}

\subsubsection{Rivers}

All three rivers: The River Purtse (PUR) River Pühajõgi (PÜH) and River Keila (KEI) are located in northern part of Estonia (Fig. 1A, B). The former two rivers represent typical mine-impacted systems in the oil shale area of North East Estonia and have long term hydrological and mining records available (dating back to 1923). These rivers have been subjected to intense human impact, mainly due to mining operations since the beginning of $20^{\text {th }}$ century $[14,15]$. In comparison, the River Keila is located approximately $150 \mathrm{~km}$ west of the oil shale mining area. Its catchment has never been affected by mining activity.

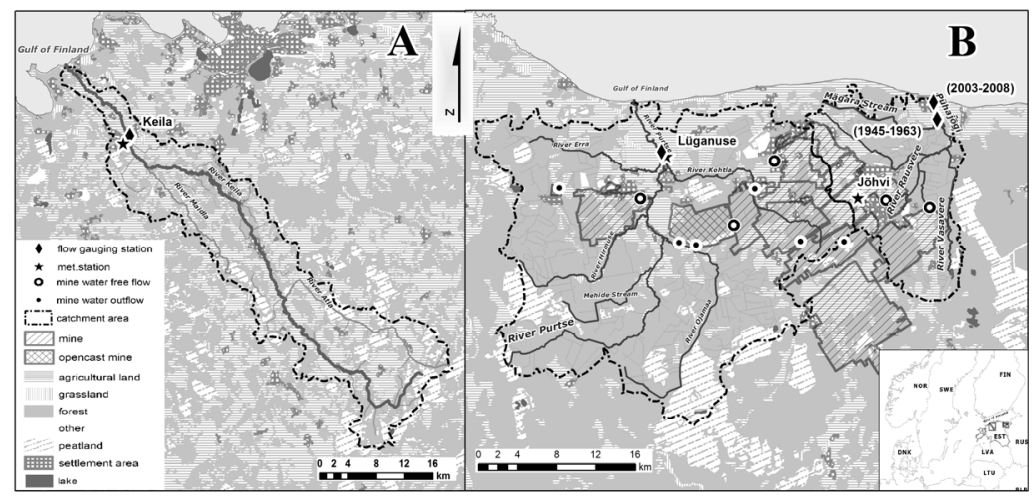

Figure 1: Location, land cover and mining area of the river Keila (A), river Purtse and river Pühajõgi (B) catchments at present time.

The River Purtse and River Keila are medium size rivers by Estonian standards (Table 1) but have similar landscape and hydrogeological conditions to the smaller River Pühajõgi. They are typical Estonian lowland rivers draining to the Baltic Sea on the Estonian Coastal Plain. The catchments are characterised by low gradient terrain, with peak catchment elevation ranging from $52 \mathrm{~m}$ (Pühajõgi ), 70m and $71 \mathrm{~m}$ (Purtse and Keila respectively). The average slope of the all studied riverbeds is about $1.80 \mathrm{~m} / \mathrm{km}$. The greatest slope (up to $5 \mathrm{~m} / \mathrm{km}$ ) occurs in the lower reaches of all streams prior discharge into the Gulf Finland, where the rivers cross the limestone escarpment of the high Baltic Klint. Therefore, in the River Purtse and River Pühajõgi rapids have been formed, and the River Keila has a 7m high waterfall, both with narrow deep valleys [16].

All catchments contain equally extensive peatland deposits and coniferous forests (Fig. 1A, B). The catchment hydrology is also influenced by land drainage associated with predominantly arable agriculture and karstic features associated with the underlying Ordovician limestone deposits and aquifer complex. 
Table 1: $\quad$ Summary physical data for the river Purtse, Pühajõgi and Keila.

\begin{tabular}{|c|c|c|c|}
\hline & River Purtse & River Pühajõgi & River Keila \\
\hline Catchment area, $\mathrm{km}^{2}$ & 809 & 196 & 682 \\
\hline Catchment morphology & fan-shape & triangular shape & elongated shape \\
\hline The mean annual run-off, $\mathrm{m} 3 / \mathrm{s}$ & 6.82 & 1.70 & 6.2 \\
\hline Length of the main river, $\mathrm{km}$ & 50 & 28 & 116 \\
\hline Tributaries over $10 \mathrm{~km}$ length & 5 & 3 & 2 \\
\hline Mean precipitation, $\mathrm{mm}$ & & 540 & 690 \\
\hline $\begin{array}{l}\text { Operating (closed) oil shale } \\
\text { mines in the catchment area }\end{array}$ & $3(6)$ & (1) & 0 \\
\hline sharing: & & (3) & 0 \\
\hline
\end{tabular}

\subsubsection{Mining area}

At present, the oil shale mining area (Fig. 1B) itself covers a territory of approximately $430 \mathrm{~km}^{2}$. The first oil shale opencast mine in the River Purtse catchment area was opened in 1918. Subsequent rapid development of the oil shale deposits has seen 24 deep mines and opencasts operate in this area. Currently only two mines and three opencasts are operating in the whole mining area [17], with some residual activity in the Purtse (Table 1). There is no present mining activity in the River Pühajõgi catchment area, with all four mines previously operating now closed.

One of the most serious problems identified is the constant change in the groundwater regime. Due to mining activity and pumping operations, the underlying Ordovician limestone deposits and aquifer complex have been totally drained. As a result an extensive cone of depression [18] stretching up to $35 \mathrm{~m}$ in depth and $2.5 \mathrm{~km}$ outside of the mining area [19] creates groundwater flow gradients towards the mines. After closure of mines in the last two decades, new massive underground water bodies have developed in the mine voids $[12,13]$.

\subsubsection{Climate}

From the climatological point of view, the River Keila, River Purtse and River Pühajõgi belong to different precipitation sub-regions of Estonia. While the River Keila is situating on the North-Western precipitation district (characterised by Keila meteorological station), the River Purtse and River Pühajõgi are situated on the North-Eastern district (Jõhvi/Lüganuse meteorological stations) [20]. However, strong correlations in seasonal rainfall are apparent between the two areas. A strong correlation of up to $r=0.82(\mathrm{p}<0.05)$ is apparent in February, with the weakest, but statistically still significant correlation $(\mathrm{p}<0.05$, $\mathrm{r}=0.30$ ), occurs in July when the precipitation series are affected by heavy showers that are unevenly distributed in time and space. Total rainfall in the areas differs by $50 \mathrm{~mm}$ in the long term average, with higher average annual rainfall reported at the Keila meteorological station (Table 1).

\subsection{Data collection}

The present study run-off analysis is based on precipitation and run-off data collected by the Estonian Meteorological and Hydrological Institute (EMHI), 
measured over varying time intervals in the catchments. Daily flow data were available for the River Purtse and River Keila over the period 1923-2005 and for the River Pühajõgi period between 1945-1963. Flow records for the periods of 1978-1990 and 2003-2005 have collected weekly in the Pühajõgi. Flow gauging stations are situated in the lower course of catchments just downstream of the catchment outlet to the Baltic Sea (Fig. 1A, B) and calibrated through spot gauging. To account for the gaps in the run-off time series data set for River Pühajõgi previously modeled data has been used here (see [15], for a description of the model). Precipitation data has been collated from two tipping bucket rain gauges at Jõhvi and Keila (aggregated daily data available between 1960present) and Lüganuse (daily data available between 1939-present). All meteorological stations are shown on the Fig.1A, B. Mean oil shale mine water discharge rates $\left(\mathrm{m}^{3} /\right.$ year) and mining area $\left(\mathrm{km}^{2}\right)$ data have also been collated from digital and hard copy records kept by the Eesti Energia Kaevandused Ltd.

\subsection{Methods}

All run-off frequency analyses during the period 1923-2005 are worked out by simple conceptual daily rainfall-runoff-mine water, using the Hewlett Runoff Model [21], which has been modified to their hydrological regime. To study changes in minimum run-off in the River Keila, River Pühajõgi and River Purtse catchment area, non parametric methods (Mann Whitney Test, given data are not normal even after log-transformation: Kolmogorov-Smirnov: $p>0.05$ ) and Rodionov's Regime Shifts Algorithm (STARS) were used. Basic deductive statistical analyses were undertaken in SPSS v.15. The STARS software (Excel macro) is based on a sequential t-test analysis [22, 23]. It is designed to characterise abrupt changes in time series. In our studies the shift frequency regime had following parameters: cut-off length was 10, Huber's Weight Parameter was 1 and $\mathrm{p}=0.1$, where the co-called pre-whitening number was implemented. It is presumed that regime shift in different parameters are associated when changes occur within a 3 year period.

Spatial data were created by MapInfo where land cover and topography layers are taken from Corine Land Cover 2006 with 25m resolution. Presented maps are also updated with the specific data such as excavation work in the river bed, which was carried out by the Estonian Agricultural Board. Furthermore, during 2008-2009 additional fieldwork took place on the River Purtse and in summer of 2010 on the River Pühajõgi. Walkover survey of the catchments validated the current flowpaths and catchment boundaries.

\section{Results and discussion}

\subsection{Long term regime}

Mean precipitation in North Estonia is between 640-690 mm/yr and average evapotranspiration rate is $50-90 \%$ of precipitation (EMHI). The long term regime of the rivers follows a typical temperature-controlled northern temperate 
zone lowland regime [24]. Catchments over $600 \mathrm{~km}^{2}$ in area typically have average flow rates over $7 \mathrm{~m}^{3} / \mathrm{s}$ [16]. Run-off maxima occur between March and May with snowmelt following spring temperature rises. Flow minima in all catchments occur during both summer (June-August) and winter (DecemberFebruary) baseflow periods.

This baseflow is sustained predominantly by drainage from extensive peatland deposits in headwater areas of the Purtse and forest-covered peat deposits in the Pühajõgi and Keila under natural flow conditions (Fig. 2). Because of the clear seasonal variation in climate in this region the difference between maximum and minimum run-off can be up to five orders of magnitude on an average annual basis.

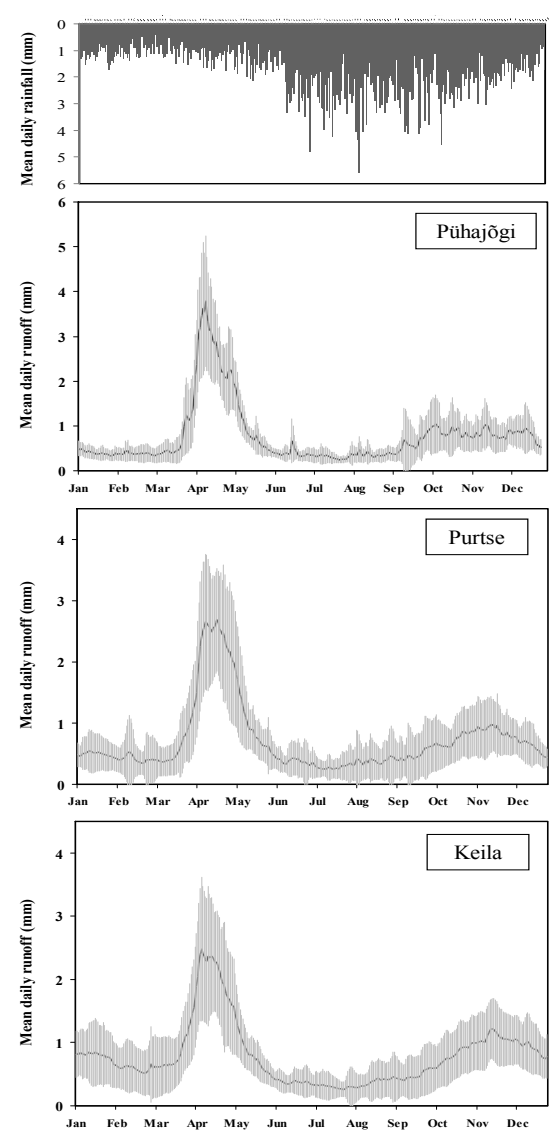

Figure 2: The mean annual precipitation and run-off of the river Pühajõgi, Purtse and Keila. Grey bars show standard deviation around mean. 


\subsection{Changes in mean annual run-off}

The relationship between the natural catchment area, the size and location of mine voids and hydrogeological gradients are decisive for variations in downstream run-off. Mine pumping operations not only have the potential to redirect incident meteoric waters from one catchment to another, but crucially lead to the contribution of (potentially deep) groundwater to surface run-off that would not have occurred previously $[25,26]$.

The groundwater content in the mine water depends mainly on an individual mining area, operating conditions and local hydrogeology [27]. The amount of extra groundwater in the River Purtse is estimated as minimal (up to 5\%) and as seen on the Fig. 3 it does not appear to affect its run-off. This would suggest that the River Purtse run-off has not been increased from existing mine water. The previously estimated $30 \%$ of mine water in the River Purtse run-off by [10] is most likely to be dominated by the surface water incident on the mining area which under natural conditions would contribute to the River Purtse run-off. In contrast, groundwater content in the mine water on the River Pühajõgi catchment area is estimated up to $80 \%$ and therefore more susceptible to mine water pumping operations [15].

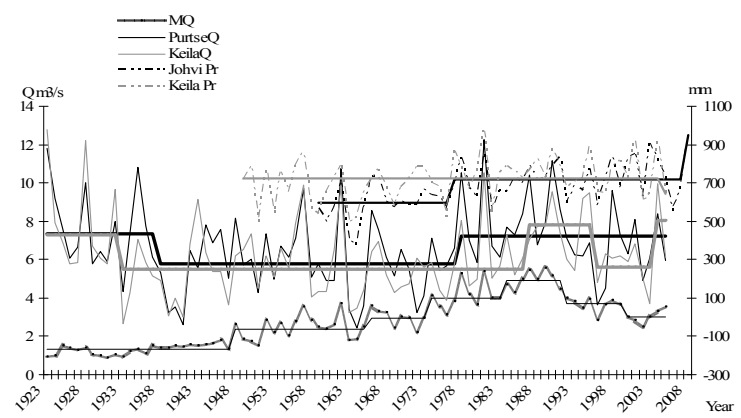

Figure 3: $\quad$ Regime shift in precipitation ( $\mathrm{Pr})$, mine water (MQ) and average daily flow $(\mathrm{Q})$ of the river Purtse and Keila.

During the early period of 1990s there was an abrupt decrease in the mine water discharge associated with a decrease in mining productivity and the closure of mines [12]. These changes are not reflected in the average flow data series. Gravity-driven drainage from mine voids after groundwater tables have rebounded after cessation of pumping are likely to account for the ongoing elevated run-off. The location of these mine water free flow points in the River Purtse and River Pühajõgi are marked on Fig. 1B.

The contribution of mine water discharge to (converted to $\mathrm{mm} / \mathrm{yr}$ over the respective catchment area) to annual average run-off is shown in Fig. 4 for the Purtse and Pühajõgi. In the early phases of the record (pre-1945), the mines in both catchments accounted for between $10 \%$ and $23 \%$ of total annual run-off. As oil shale mining expanding post- 1945 there is a rise in the volumetric importance of the mine water, which peaks at slightly over $110 \%$ of catchment outlet run-off 
in the River Pühajõgi in 1980 and $86 \%$ of catchment outlet run-off in the River Purtse in 1990. The contribution of mine water as a percentage of catchment runoff declines during the 1990s in both catchments towards pre-mining levels in the River Purtse and at levels slightly elevated above 1923 levels in the River Pühajõgi (Fig. 4).

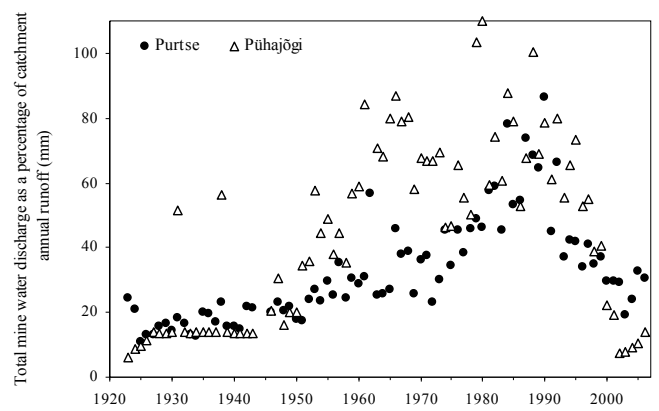

Figure 4: Mine water proportion in the river Pühajõgi and river Purtse runoff.

Simple linear regressions can also be used $(1 ; 2)$ to explain the relative importance of mine water $(\mathrm{M})$ and natural water $(\mathrm{N})$ in driving variation in river run-off (Q). Kattai et al. [19] demonstrated that typically $15 \%$ of pumped mine water re-infiltrates back to the mines through stream leakage. Therefore it is important to take into consideration that only $85 \%$ of recorded mine water is likely to contribute to river run-off. The regression describes the period 19232005 when the mine water discharge is significantly correlated with run-off in both the River Purtse and to a slightly greater degree in the smaller River Pühajõgi.

$$
\begin{aligned}
& \mathrm{Q}_{\text {PUR }}=\mathrm{N}_{\text {PUR }}+0.85 \mathrm{M}_{\text {PUR }} \Rightarrow \mathrm{r}^{2}=0.35 \\
& \mathrm{Q}_{\text {PÜH }}=\mathrm{N}_{\text {PÜH }}+0.85 \mathrm{M}_{\text {PÜH }} \Rightarrow>r^{2}=0.42
\end{aligned}
$$

\subsection{Changes in run-off minima}

With baseflow periods occurring in both summer (June-August) and winter (December-February) in the temperature controlled plains snowmelt regime in north east Estonia (Fig. 2), it is informative to assess the changes specific to summer months that are likely to be of greater ecological significance. Fig. 5 illustrates a significant $(p<0.05)$ increase in Purtse summer baseflow, which is most pronounced from the mid-1970s and corresponds with increasing mining activity. No significant trend in run-off is apparent in the similarly sized Keila data or in mean daily summer rainfall $(p<0.05)$. 

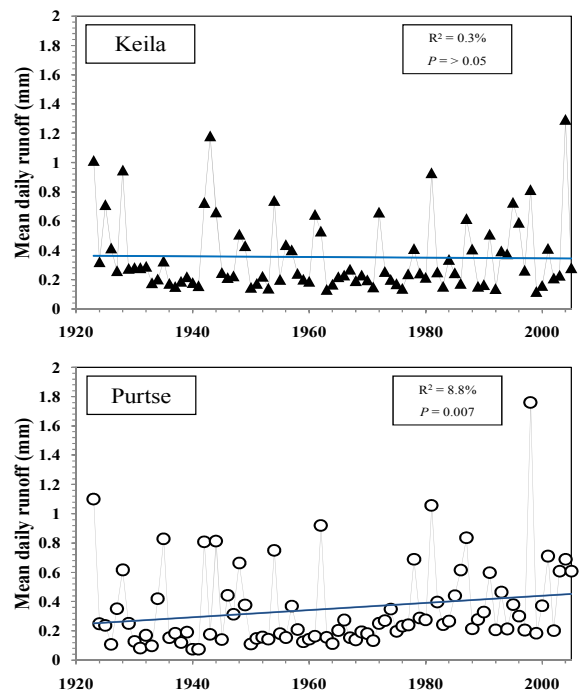

Figure 5: Trend in summer (June-August) baseflow run-off in the river Keila and Purtse.

The summer baseflow data can also be assessed using the Rodionov algorithm which identifies two distinct hydrological periods. Prior to 1970s, when the mining activity was less active, the July minimum and annual minimum run-off was much lower than during the post 1970s intense mining development (Fig. 6A, B). The River Keila contrasts this situation showing no regime shift during that time period. In Fig. 3 it is clearly seen, that in summer baseflow the mine water discharge keeps run-off minima at higher rates. The same figures also identify an increase of precipitation but much later in the time series.

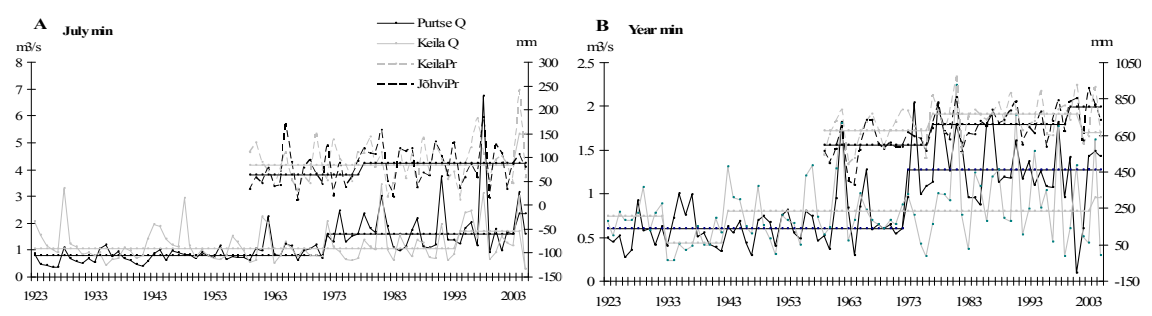

Figure 6: $\quad$ Seasonal occurrence of minimum run-off $(\mathrm{Q})$ and precipitation $(\mathrm{Pr})$.

Overall, the River Purtse and River Pühajõgi median summer baseflows (JunAug) are consistently and significantly higher during from 1953 onwards (Table 2). One of the main controls on the increased baseflow in the River Pühajõgi catchment is likely to be the Tammiku mine which can contribute up to $80 \%$ of 
the flow to the river. Because of mine water discharge to the River Pühajõgi catchment area, the water flow continues through the year in the riverbed even in drought years when most of the small Estonian rivers dry out [16].

There was no recorded significant difference in the River Keila median summer baseflow between the phases (Table 2). There are also no significant differences in median summer rainfall or during these two contrasting periods of mining intensity, suggesting that the hydrological changes are most likely driven predominantly by mining activity.

Table 2: $\quad$ Median and range of summer (Jun-Aug) daily flow and rainfall during differing periods of mining activity in the rivers Purste, Pühajõgi, and Keila. Non-mining phase $=1923-1952$; Mining phase $=1953-2005$.

\begin{tabular}{|c|c|c|c|c|c|c|c|c|c|}
\hline & \multicolumn{3}{|c|}{ Purtse } & \multicolumn{3}{|c|}{ Pühajõgi } & \multicolumn{3}{|c|}{ Keila } \\
\hline & $\begin{array}{c}\text { Non- } \\
\text { mining }\end{array}$ & Mining & Significant? & $\begin{array}{c}\text { Non- } \\
\text { mining }\end{array}$ & Mining & Significant? & $\begin{array}{l}\text { Non- } \\
\text { mining }\end{array}$ & Mining & Significant? \\
\hline Period & summer & summer & summer & summer & summer & summer & summer & summer & summer \\
\hline $\begin{array}{c}\text { Median } \\
\text { flow } \\
\left(\mathrm{m}^{3} \mathrm{~s}^{-1}\right)\end{array}$ & 1.3 & 2.0 & * & 0.38 & 0.63 & $*$ & 3.0 & 2.6 & \# \\
\hline Range & $\begin{array}{c}0.27- \\
61.9\end{array}$ & $\begin{array}{c}0.29- \\
43.9\end{array}$ & & $0.1-7.75$ & $0.21-5.2$ & & $\begin{array}{l}0.35- \\
29.5\end{array}$ & $\begin{array}{l}0.28- \\
44 . .0\end{array}$ & \\
\hline $\begin{array}{c}\text { Median } \\
\text { rainfall } \\
(\mathrm{mm})\end{array}$ & 74.7 & 72.6 & \# & 73.6 & 73.1 & \# & 74.7 & 72.6 & \# \\
\hline Range & $17-205$ & $4-196$ & & $0-205$ & $10-166$ & & $17-205$ & $4-196$ & \\
\hline
\end{tabular}

\section{Conclusions}

The most pronounced effects on regime related to mine water discharge are most visible in the smaller River Pühajõgi catchment. The current analyses show that the annual mine water discharged to the River Purtse catchment area does not affect its annual run-off due to the low percentage of extra groundwater in the mine water. Long term variability in run-off regime also shift appears to be driven primarily by precipitation. However, mine water discharge can affect baseflow average and minima, thus increasing the amount of the run-off during summer months. The additional groundwater discharged to surface waters by mine pumping operations is likely the key control on this augmentation. The amount of extra groundwater in the mine water depends mainly on an individual mining area and site-specific drainage changes both with engineered points of discharge of pumped mine water, as well as the more stochastic position of gravity-driven free flows after pumping has ceased.

The regime change in itself could be of significance for aquatic biota by changing the physical characteristics of streams during baseflow, with increasing velocity and less variability in regime. Additionally, there may be associated impacts on aquatic biota associated with changed thermal conditions (with the volumetric significance of large quantities of relatively cooler groundwater from 
the mines) and changed water quality. The ecological significance of changed flow regimes should be a focus of future study.

\section{Acknowledgements}

Present study is financed by the Ministry of Education and Science of Estonia (grant SF0180127s08), the Estonian Science Foundation (grant 7527). Appreciation goes to Eero Piirisalu and Aarne Luud, who helped with fieldwork studies.

\section{References}

[1] Mayes, W.M, Potter, H.A.B. \& Jarvis, A.P. Inventory of aquatic contaminant flux arising from historical non-coal mining in England and Wales. Science of the Total Environment 408, pp 3576-3583, 2010

[2] Nriagu, J.O. \& Pacyna, J.M. Quantitative assessment of world-wide contamination of air, water and soils by trace metals. Nature 333, pp 134139, 1988

[3] Younger, P.L, Banwart, S.A \& Hedin, R.S. Mine water: hydrology, pollution, remediation. Kluwer Academic Publishers, Holland, pp 408, 2002

[4] PIRAMID Consortium, 2003. Engineering guidelines for the passive remediation of acidic and/or metalliferous mine drainage and similar wastewaters. European Commission $5^{\text {th }}$ Framework RTD Project no. EVK1-CT-1999-000021 "Passive in-situ remediation of acidic mine/industrial drainage" (PIRAMID), Univ of Newcastle upon Tyne, Newcastle upon Tyne.

[5] Negley, T.L. \& Eshleman, K.N. Comparison of stormflow responses of surface-mined and forested watersheds in the Appalachian Mountains, USA. Hydrological Processes 20, pp 3467-3483, 2006.

[6] Ferrari, J.R., Lookingbill, T.R., McCormick, B., Townsend, P.A. \& Eshleman, K.N. Surface mining and reclamation effects on flood response of watersheds in the central Appalachia Plateau region. Water Recourses Research 45, pp W04407, 2009.

[7] Finlinson, B. \& Groves, A. Hydrological effects of mineral workings: new guidelines to safeguard nature conservation areas. Quarry Management 21, 21-26, 1994.

[8] Mayes, W.M., Large, A.R.G. \& Younger, P.L. The impact of pumped groundwater from a de-watered Magnesian limestone quarry on an adjacent wetland. Environmental Pollution 138, pp 444-455, 2005.

[9] Parakhonski, E. Conditions of formation of wastewaters discharged from the oil shale mines and open pits. Tallinn, 1983. (In Russian).

[10] Rätsep, A. \& Liblik V. Technogenic water flows generated by oil shale mining: impact on Purtse catchment rivers. Oil Shale 17(2), pp 95-112, 2000 . 
[11] Erg, K. Sulphate balance of lakes and shallow groundwater in the Vasavere buried valley, Northeast Estonia. Oil Shale 20(4), pp 477-489, 2003.

[12] Reinsalu, E., Valgma, I., Lind, H. \& Sokman, K. Technogenic water in closed oil shale mines. Oil Shale 23(1), pp 15-28, 2006.

[13] Lind, H. Groundwater Flow Model of Oil Shale Mining Area. Oil Shale 27(3), pp 258 - 273, 2010.

[14] Rätsep, A. \& Liblik, V. The influence of polluted water flows on hydrological and hydrochemical conditions of Purtse catchment rivers, NE Estonia. Nordic Hydrology 32(3), pp 215-226, 2001.

[15] Vaht, R. \& Rätsep, A. Impact of oil shale mine water on hydrology and run-off of a small river. The Pühajõgi River case study. Oil Shale 26(1), pp 84-93, 2009.

[16] Järvekülg, A. Estonian Rivers. Tartu, Institute of Agriculural and Environmental Sciences, University of Life Sciences, pp 750, 2001. (In Estonian, summary in English).

[17] Reinsalu, E. Introduction. In: Varb, N. \& Tambet, Ü. (ed), 90 Years of Oil Shale Mining In Estonia. Technology and People. Tallinn, Geotrail KS Ltd, pp 6-10, 2008. (In Estonian).

[18] Erg, K. \& Pastarus, J-R. Hydrogeologic impacts in the Estonian oil shale deposit. International Journal of Mining, Reclamation and Environment 22(4), pp 300-310, 2008.

[19] Kattai, V., Saarde, T. \& Savitski, L. Estonian Oil Shale: Geology, Resources, Mining Conditions. Tallinn, Geological Survey of Estonia, pp 226, 2000. (In Estonian).

[20] Jaagus, J. Periodicity of Precipitation in Estonia. In: Kaare, T., Mardiste, H. \& Punning, J.-M. (ed.), Estonia, Man and Nature. Tallinn, Estonian Geographical Society, pp 43-53, 1992.

[21] Burnett, A.D. \& Watson, I. Hydrology, an Environmental Approach. New York, 1995.

[22] Rodionov, S.N. A Sequential Algorithm for Testing Climate Regime Shifts. Geophysical Research Letters 31, pp L09204, 2004.

[23] Rodionov, S.N. \& Overland, J.E. Application of a Sequential Regime Shift Detection Method to the Bering Sea Ecosystem. The ICES Journal of Marine Science, 62, 328-332, 2005.

[24] Shaw E.M Hydrology in practice, third edition. London, Chapman \& Hall, 569 p, 1994.

[25] Golf, W. Contribution concerning the Flow Rates of Rivers Transporting Drain Waters of Open-Cast Mines. International Association of Scientific Hydrology (IASH). Hydrological Aspects of the Utilization of Water. 76, pp 306-316, 1968.

[26] Hester, R.E. \& Harrison, R.M. Mining and its environmental impact. Cambridge, Royal Society of Chemistry, 146 p, 1994.

[27] Barnes, T.M. Treatment of the gravity minewater discharge at Deerplay Mine, Burnley, UK. $7^{\text {th }}$ International Mine Water Association Congress, Ustron 2, pp 344-35, 2000. 